\title{
Computer programs for the classification and nomenclature of igneous rocks
}

\author{
${ }^{1}$ Departamento de Sistemas Energéticos, Instituto de Energías Renovables, Universidad Nacional Autónoma de México, Privada Xochicalco s/ \\ no., Centro, Apartado Postal 34, Temixco, Mor., 62580, México.E-mail: spv@ier.unam.mx \\ ${ }^{2}$ Posgrado en Ingeniería, Instituto de Energías Renovables, Universidad Nacional Autónoma de México, Privada Xochicalco s/no., Centro, \\ Apartado Postal 34, Temixco, Mor., 62580, México.E-mail: marig@ier.unam.mx
}

We review the most important computer programs for the classification of igneous rocks and point out those that follow the recommendations of the International Union of Geological Sciences (IUGS). A new program "Igneous Rock Classification System" (IgRoCS), written in Visual Basic, is then described in detail. IgRoCS allows the user to follow strictly the IUGS classification and nomenclature scheme for igneous rocks. The special rocks are first classified, then plutonic rocks are named after the IUGS mineralogical classification, next high$\mathrm{Mg}$ and picritic volcanic rocks are identified from the IUGS criteria, and finally other volcanic rocks are classified according to the TAS diagram and CIPW norm. The chemical classification of volcanic rocks can also be achieved directly without going through the classification of other rock types. The IgRoCS program incorporates the revised standard igneous norm. Thus, the use of this new software is encouraged for a strict application of the IUGS recommendations for igneous rock classification and nomenclature.

\section{Introduction}

For several decades, the International Union of Geological Sciences (IUGS) has been concerned with an appropriate classification scheme for igneous rocks. Under the umbrella of the IUGS, numerous renowned scientists, such as Albert Streckeisen, Bruno Zanettin, Mike Le Bas, Bernard Bonin, and Roger Le Maitre, among others, have pursued the goal of putting forth a standard procedure for igneous rock classification, which should be followed by everyone.

Thus, on the recommendation of Professor T.F.W. Barth, the Subcommission on the Systematics of Igneous Rocks was constituted under the IUGS Commission on Petrology, which commenced its work back in 1970 .

The Sub-commission commenced with the plutonic rocks and gave its final recommendations as a monumental paper by Streckeisen (1976), which has been highly used, with around 1030 citations in SCI-indexed international journals, as confirmed by us on September $1^{\text {st }}, 2012$ in the Science Citation Index (SCI) database of the Institute for Scientific Information (ISI), Philadelphia. The large number of citations in different international journals gives a clear-cut idea of the worldwide use of such work.

The attention of the Sub-commission then shifted to volcanic rocks. Among the several short documents, the most noticeable has been the highly cited publication by Le Bas et al. (1986) specifically geared for the classification of volcanic rocks (with over 1800 citations in international journals SCI-ISI, as on September $\left.1^{\text {st }}, 2012\right)$. The well-known TAS (Total Alkalis versus Silica) classification, although improperly used by most scientists even today, was the most important outcome of this joint effort. The classification scheme for the high$\mathrm{Mg}$ and picritic volcanic rocks prior to the TAS classification was also put forth by Le Bas (2000), with around 160 citations in international journals.

Similarly, the classification of pyroclastic, charnockitic, carbonatitic, alkaline and other rocks was also considered, and the Sub-commission realized it to be of utmost importance to present the results of classification and nomenclature as a book whose first edition was by Le Maitre et al. (1989), which has been a highly used and cited document (with around 1500 citations). Then appeared the second edition of this book (Le Maitre et al., 2002), with around 460 citations.

In spite of so many citations of the IUGS proposals and recommendations, it appears that the rock classification as practiced by most scientists lacks the rigor suggested by the IUGS proponents. For example, for volcanic rock classification the TAS scheme practiced by most people does not take into account the Fe-oxidation and $100 \%$ anhydrous basis adjustments, because the measured $\mathrm{SiO}_{2}$ and $\mathrm{Na}_{2} \mathrm{O}+\mathrm{K}_{2} \mathrm{O}$ values are simply plotted, without any thoughts on the interdependency of compositional data and closure problems (Chayes, 1960; Aitchison, 1986; Verma, 2010). It is well known that the sum of the measured major elements (or oxides) is seldom $100 \%$ and volatile components may constitute a significant part of this total. Besides, more importantly, both oxidation states $\left(\mathrm{Fe}_{2} \mathrm{O}_{3}\right.$ and $\left.\mathrm{FeO}\right)$ are seldom separately measured. Therefore, by the use of measured crude compositions of $\mathrm{SiO}_{2}$ and $\mathrm{Na}_{2} \mathrm{O}+\mathrm{K}_{2} \mathrm{O}$, the recommendations of Le Bas et al. (1986) or Le Maitre et al. $(1989,2002)$ are not really taken into account in the TAS diagram. Similarly, not all CIPW norm schemes lead to the same answer (Middlemost, 1989; Le Maitre, 2002; Verma et al., 2003). These considerations, therefore, should be a major issue to be addressed, if we were to count on a common "language" for the nomenclature of volcanic rocks.

\section{Existing computer programs}

We will concentrate on the characteristics of the existing software 
for igneous rock classification and nomenclature, but will not comment on other applications, such as several kinds of simple bivariate, ternary, multi-element normalized, or discrimination diagrams popular among the Earth scientists. The readers can explore these aspects themselves in the computer programs cited in this review, or elsewhere, e.g. Rollinson (1993, a popular book with around 1180 citations in SCIISI journals).

\section{WINROCK (1997-2012)}

This computer program, initially proposed in 1997, was updated extensively in 2012 (R.A. Kanen; http://www.geologynet.com). WINROCK is commercially available as a single user version for AU \$399.00 (http://www.geologynet.com/order.htm). It is capable of providing a wide range of IUGS diagrams for rock classification. However, WINROCK does not classify all special rocks suggested by Le Maitre et al. (2002). The program does not validate data for the QAPF diagram. Similarly, for volcanic rock classification the program requires the user to input the $\mathrm{Fe}$-oxidation ratio, because the program does not include the calculation scheme proposed by Le Maitre (1976a) or Middlemost (1989).

Because the program was not published in an international journal, it is not easy to check the impact of this software in terms of total citations in international journals.

\section{IUGSTAS software package (2002)}

In Appendix C of the book by Le Maitre et al. (2002), Le Maitre (2002) described a collection of C++ programs (IUGSTAS software package) for implementing the TAS classification for volcanic rocks (Le Bas et al., 1986). According to Le Maitre (2002), this software corrected the then prevailing common mistakes and rounding errors in the CIPW norm (Cross et al., 1902) calculation schemes (Johannsen, 1931; Kelsey, 1965).

This program is available from the Cambridge University Press, as a part of the book by Le Maitre et al. (2002). Although the author stated that he extensively used this code in the CLAIR data system (Le Maitre, 1973, 1976b), its use by others has been rather limited, with the unfortunate consequence that the problem of the incorrect use of the TAS classification still persists.

\section{SINCLAS (2002)}

This computer program "Standard Igneous Norm and Volcanic Rock CLAssification System” (SINCLAS; Verma et al., 2002, 2003), written in Visual Basic, was meant for the classification of volcanic rocks fully consistent with the IUGS recommendations (Le Bas et al., 1986), including the special high-Mg and picritic rocks (Le Bas, 2000), such as meimechite, komatiite, picrite, and boninite. SINCLAS corrects the measured concentrations to $100 \%$ on an anhydrous basis after proper Fe-oxidation adjustment (Le Maitre, 1976a; Middlemost, 1989). It also allows the use of actually measured $\mathrm{Fe}_{2} \mathrm{O}_{3}$ and $\mathrm{FeO}$ concentrations. Because Le Bas et al. (1986) also proposed the use of normative minerals for volcanic rock subroot names, SINCLAS allows precise and accurate norm calculations according to the standard igneous norm (a revised CIPW norm) scheme proposed by Verma et al. (2003). Furthermore, this program provides information on the magma type (ultrabasic, basic, intermediate, or acid) from the adjusted compositions. This information has been used for multi-dimensional tectonomagmatic discrimination diagrams recently proposed for igneous rocks (e.g., Verma, 2010, 2012; Verma and Agrawal, 2011; Verma et al., 2012).

SINCLAS (Verma et al., 2002) is freely available on request to the first author. It has been used in the literature for the TAS diagram and volcanic rock nomenclature (with around 80 citations in SCI-ISI international journals for rock classification purposes). A few years ago, Pruseth (2009) proposed new formulae for the calculation of the CIPW norm and claimed that they performed better than the SINCLAS computer program.

\section{IgPet (2006-2007)}

First introduced by Carr (1995), its current updated (2006-2007) version can be purchased as a single user version for US $\$ 199.00$ from RockWare Inc., Golden, CO 80401, USA (http:// www.rockware.com). This program facilitates the TAS classification and CIPW norm calculations, as well as allows the use of some mineralogical diagrams, although the latter do not seem to be those required by the IUGS classification scheme for plutonic rocks. Further, it is not clear if IgPet allows different types of Fe-oxidation adjustments as readily available in SINCLAS.

\section{GCDKit (2003-2011)}

GeoChemical Data ToolKit (GCDKit; http://www.gcdkit.org), written in language $\mathrm{R}$ and first reported by Janousek et al. (2006), has its updated version 3.0 available in 2011 (Janousek et al., 2011). This freely available program is capable of providing the QAPF classification for plutonic (Streckeisen, 1974) and volcanic (Streckeisen, 1978) rocks, TAS diagram (Le Bas et al., 1986; Middlemost, 1994), and the CIPW norm calculations. Other IUGS recommendations such as those for the classification of special rocks are not considered. GCDKit in its first documentation in an international journal (Janousek et al., 2006) did not mention the prior existence of the SINCLAS computer program. Nevertheless, mainly for the purpose of other tasks and not for rock classification, GCDKit has been cited in more than 70 papers in SCI-ISI journals.

\section{PetroGraph (2005)}

This freely available software permits rock classification from the TAS diagram, both for volcanic (Le Bas et al., 1986) and plutonic (Cox et al., 1979) rocks. The IUGS recommendations for plutonic rock nomenclature, such as the use of the QAPF double-triangle, cannot be followed. Further, it is not clear if the program allows for the prior adjustment of measured compositions on an anhydrous basis, nor is there any mention of Fe-oxidation ratio adjustment. The authors failed to acknowledge the prior computer program SINCLAS for this purpose. Although not specifically used for rock classification, this program has been cited in around 20 papers included in SCI-ISI journals.

\section{New computer program IgRoCS (2012)}

IgRoCS (Igneous Rock Classification System; this work), written in Visual Basic and Net Framework, strictly follows all IUGS recommendations for the classification and nomenclature of igneous rocks (Le Maitre et al., 2002). Figure 1 provides a schematic flow 


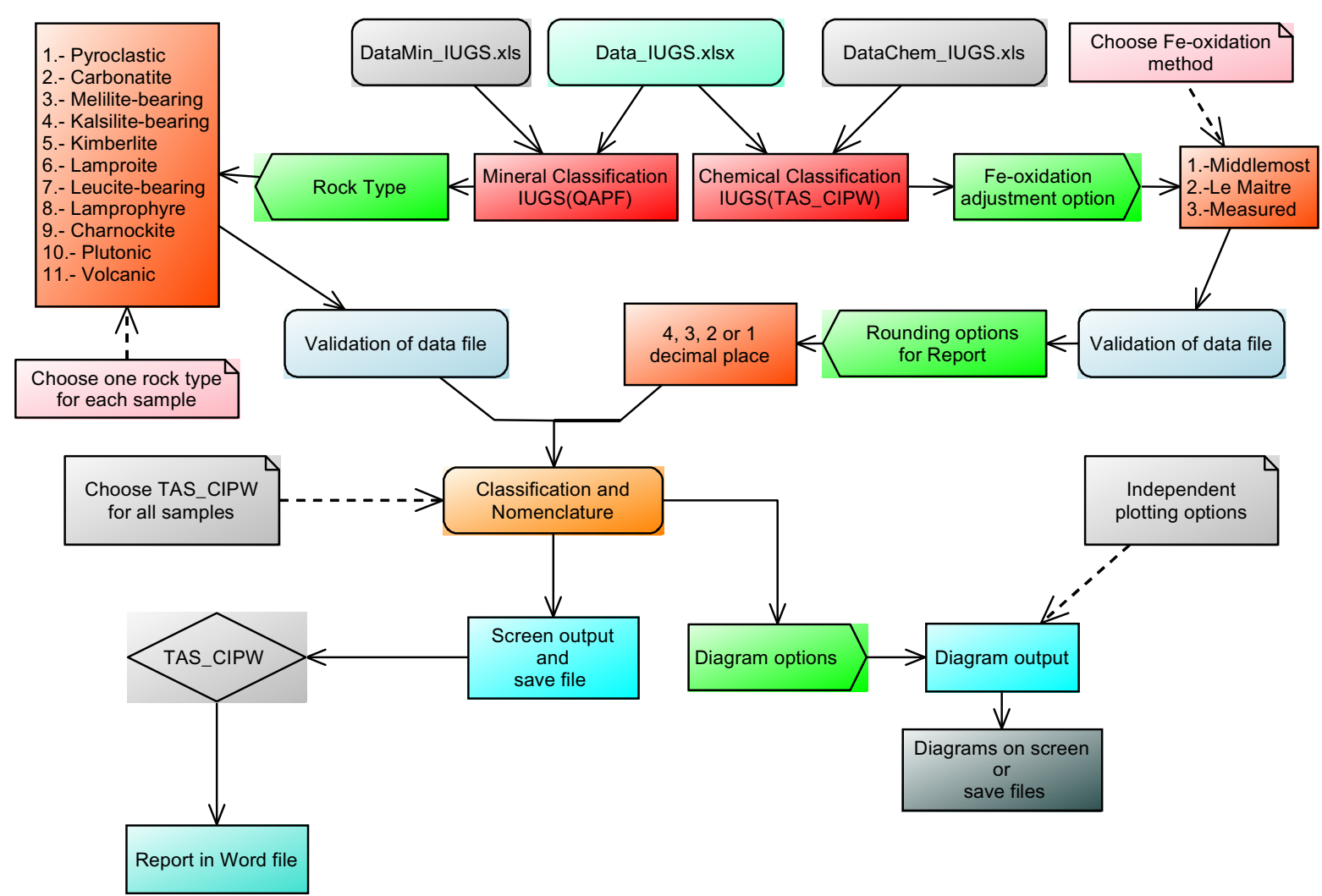

Figure 1. Simplified flow diagram of the IgRoCS (Igneous Rock Classification System) program presented in this work for the classification and nomenclature of igneous rocks.

diagram for IgRoCS, which is self-explanatory. All results, including the rock nomenclature, can be saved in Excel output files.

Before classifying the conventional plutonic or volcanic rocks, the program first allows the classification of special rocks, namely, pyroclastic, carbonatite, melilite-bearing rock, kalsilite-bearing rock, kimberlite, lamproite, leucite-bearing rock, lamprophyre, and charnockite. Thus, all these nomenclatures strictly follow the IUGS scheme (Le Maitre et al., 2002), except for kimberlites, whose classification into Group I and Group II types is unclear from the IUGS recommendation. This nomenclature was achieved from Howarth et al. (2011; see R.H. Mitchell's 1995 book citation in this paper).

For plutonic rocks, other ternary diagrams for modal classification of gabbroic and ultramafic rocks follow the QAPF double-triangle scheme. IgRoCS validates these modal data for internal consistency.

For volcanic rocks, the standard IUGS scheme is strictly followed. First, IgRoCS identifies the high-Mg and pricritic volcanic rocks from the criteria summarized by Le Bas (2000). The program contains an updated and corrected version of SINCLAS. IgRoCS now provides highly accurate values of normative minerals according to the revised CIPW norm scheme (Verma et al., 2003). We corrected some minor errors in the revised norm of Verma et al. (2003). These are as follows: (a) instead of using fixed molecular weights for diopside (clinoferrosilite) and pyrite (pr), variable weights were calculated and used; (b) in step 16, the third line should read nS instead of $\mathrm{nFeO}$; (c) in step 39, the crystallization index (C.I.) was calculated from the corrected equation 47, in which the final term should be hy-Mg instead of hy-Fe; and (d) the EN_NORM and FS_NORM variables in the SINCLAS output were changed to DIM_NORM (Mg-type normative diopside) and DIF_NORM (Fe-type normative diopside), respectively.
IgRoCS provides accurately calculated normative mineral abundances in the excel output (rather than the rounded values for reports in MS Word). With these corrections in the revised CIPW norm, IgRoCS provides an almost perfect (100\% sum) results for the normative minerals.

For IgRoCS, one complete file for the newer version of Excel (Data_IUGS.xlsx) or two example files for older version of Excel (DataMin_IUGS.xls and DataChem_IUGS.xls) are provided. The complete data file contains 444 columns, whereas the two older version files contain 245 and 242 columns, respectively. The data file is validated before its use in rock classification. These example files (or part of them) can be used to practice and familiarize with the program. Three templates (Template_IUGS.xlsx, TemplateMin_IUGS.xls and TemplateChem_IUGS.xls) are also available for inputting data for specific applications. Similarly, simpler example files in excel (xls) format for the mineralogical classification of a given rock type are also available from any of the authors. These files are as follows: O1DataPyro_IUGS, artificial data prepared to illustrate the use of the program; 02DataCarbo_IUGS, data from Le Bas (1999), Houzar and Novák (2002), and Woodard and Hölttä (2005); 03DataMeli_IUGS, data from Dunworth and Bell (1998) and Dunworth and Wilson (1998); 04DataKals_IUGS, data from Bellezza et al. (2004); 05DataKimb_IUGS, data from Becker and Le Roex (2006) and Howarth et al. (2011); O6DataLamp_IUGS, data from Altherr et al. (2004); O7DataLeuc_IUGS, data from Lloyd et al. (1991); 08DataLamprophyre_IUGS, data from Tappe et al. (2004); 09DataChar_IUGS, data from Beard et al. (1994); and 10DataPlut_IUGS, data from Gomes and Neiva (2005) and Antunes et al. (2009).

As an application of the IgRoCS program for volcanic rock 
classification, we compiled in the DataChem_IUGS.xls file geochemical data for 467 representative samples of mostly volcanic rocks. Some intrusive rocks were also included to highlight the use of IgRoCS when the mineralogical information is not available or when the user is interested in deciphering the magma equivalent for their rock samples, particularly for their use in appropriate tectonomagmatic discrimination diagrams (e.g. Verma et al., 2006, 2012; Verma and Agrawal, 2011). Similarly, some older rocks were also included, because no reliable proposal for their classification is yet available (see Verma et al., 2010, for the poor performance of such classification diagrams). Therefore, the TAS and CIPW norm classification can be tentatively used until new multi-dimensional diagrams currently under preparation by S.P. Verma and collaborators are proposed.

For establishing the DataChem_IUGS.xls file, numerous sources were considered to achieve a worldwide representation of all rock types, but at the same time, limiting the total number of samples so that in a TAS diagram the data could be easily visualized. Their sources were as follows (listed alphabetically for the authors): Abdel-Rahman and Lease (2011); Agostini (2003); Agostini et al. (2006, 2007, 2010); Aguirre-Díaz and McDowell (2000); Agustín-Flores et al. (2011); Ahmad et al. (2008); Ahmadian et al. (2009); Akal (2003); Alam et al. (2004); Albrecht and Goldstein (2000); Aldanmaz et al. (2000, 2006, 2008); Alici et al. (2002); Arce et al. (2008); Arnórsson et al. (2002); Arpa et al. (2008); Avanzinelli et al. (2008); Avellán et al. (2012); Ayabe et al. (2012); Ayalew et al. (2006); Aydar et al. (2003); Aydin et al. (2008); Bachmann et al. (2002); Bagci et al. (2008); Bailey et al. (2009); Ban et al. (2007); Barker et al. (2009); Barling et al. (1994); Barrat et al. (2003); Bayat and Torabi (2011); Beccaluva et al. (2002); Beier et al. (2006, 2008); Benoit et al. (2002); Bergmanise et al. (2000); Blatterand Hammersley (2010); Blatter et al. (2001, 2007); Boari et al. (2009); Bolge et al. (2006); Booden et al. (2011, 2012); Bruni et al. (2008); Bryan (2006); Bryant et al. (2006); Cadoux and Pinti (2010); Calmus et al. (2003, 2010);
Carmichael et al. (2006); Carn and Pyle (2001); Carrasco-Núñez et al. (2010); Chadwick et al. (2007); Chakrabarti et al. (2009); Chang et al. (2009); Chen et al. (2012); Churikova et al. (2001); Conly et al. (2005); Conticelli et al. (2009); Coogan et al. (2001); Corgne et al. (2001); Cousens et al. (2003); Çubukçu et al. (2012); Cucciniello et al. (2011); Cunningham et al. (2009); de Lima et al. (2011); Deering et al. (2011, 2012); Dilek et al. (2010); Ding et al. (2003); Dini et al. (2002); Doucelance et al. (2003); Elburg et al. (2003); Elitok et al. (2010); Ferlito et al. (2009); Fontijn et al. (2010); Fretzdorfand and Haase (2002); Frey et al. (2000); Gao et al. (2010); García Tovar (2009); Geldmacher and Hoernle (2000); Gorring and Kay (2001); Guzman et al. (2011); Haase et al. (2002, 2004); Hanyu et al. (2011); Harper (2003); Hawkins and Ishizuka (2009); Hekinian et al. (2003); Hoke and Lamb (2007); Holm et al. (2006); Horz et al. (2004); Hou et al. (2004); Hsu et al. (2000); Ilbeyli et al. (2004); Ireland et al. (2009); Ishizuka et al. (2002); Jian et al. (2009); Jorgensen and Holm (2002); Jutzeler et al. (2010); Karsli et al. (2008); Kawabata et al. (2011); Kerrich and Manikyamba (2012); Kim et al. (2008); Kimura et al. (2001); Koprubasi and Aldanmaz (2004); Krochert and Buchner (2009); Ma et al. (2011); Mahéo et al. (2009); Manikyamba et al. (2005); Marshall et al. (2009); Martynov et al. (2010); Massaferro et al. (2006); Melluso et al. (2010); Nikogosian and Van Bergen (2010); Nonnotte et al. (2011); Ortiz-Hernández et al. (2003); Owen (2008); Özdemir et al. (2011); Pappalardo et al. (2008); Patino et al. (2003); Peccerillo et al. (2003); Perini et al. (2004); Polat et al. (2002); Price et al. (2003); Ren et al. (2004); Robin et al. (2009); Rogers et al. (2004); Rolland et al. (2009); Rollinson (2009); Ronga et al. (2010); Rooney et al. (2007); Rosa et al. (2004, 2006); Schaaf et al. (2005); Schuth et al. (2004, 2009); Shane et al. (2005); Sheth and Melluso (2008); Sheth et al. (2003); Shinjo et al. (2011); Shukuno et al. (2006); Siebert and Carrasco (2002); Spath et al. (2001); Srivastava (2006); Sruoga et al. (2005); Tamura et al. (2009); Tatar et al. (2007); Taylor et al. (1994); Tian et al. (2011); Torabi (2009); Turner et al. (2012); Upton et al. (2000); Verma (2000); Vigouroux et al. (2008); Wang et

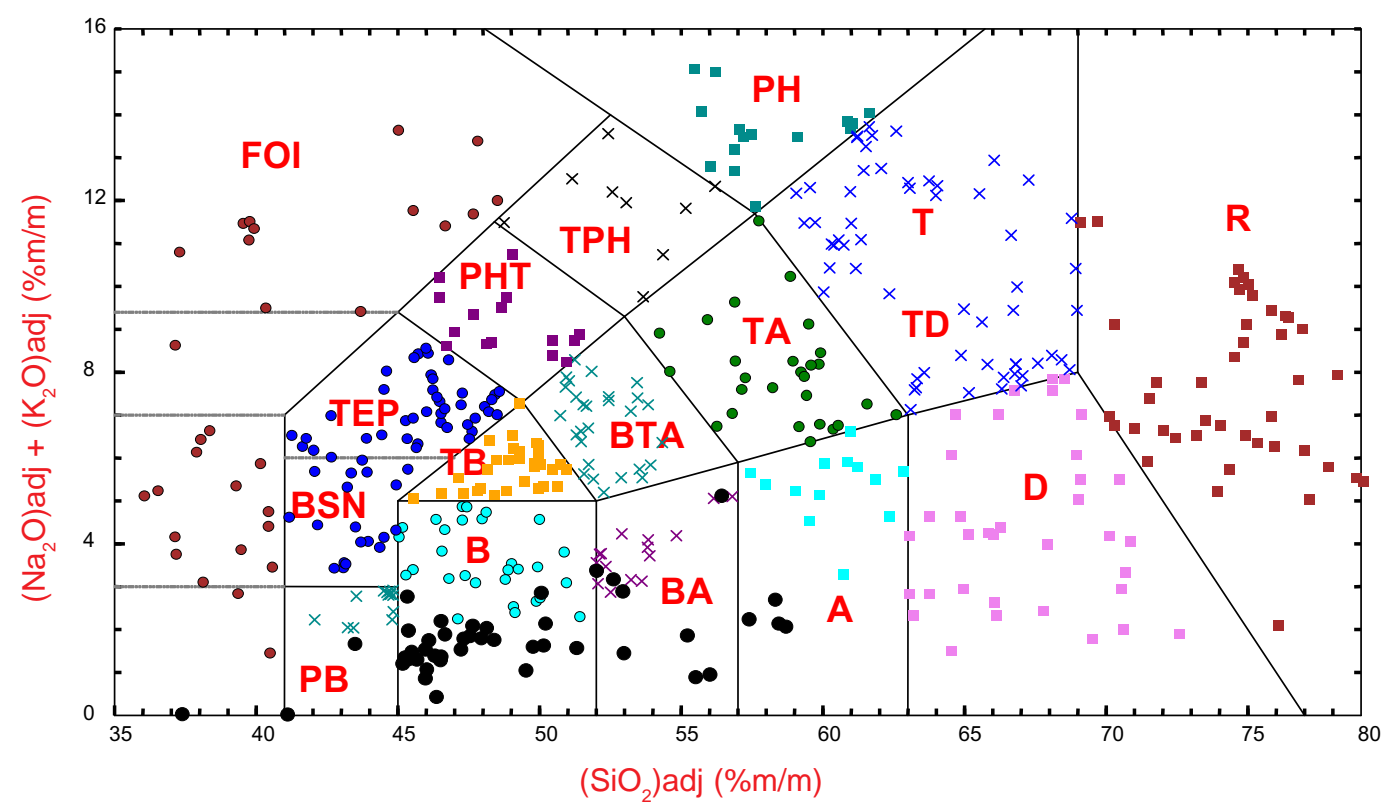

Figure 2. The TAS diagram for the samples compiled in DataChem_IUGS.xls file. See text for the literature source of data. Filled black circles show the high-Mg and picritic rocks, whereas symbols used for other rock types are self-explanatory. The abbreviations used are the same as in Verma et al. (2002): $A=$ Andesite, $B=B a s a l t, B A=B a s a l t i c$ andesite, BSN =Basanite, BTA =Basaltic trachyandesite, $D=$ Dacite,$F O I=$ Foidite,$P B=$ Picrobasalt,$P H=$ Phonolite, $P H T=$ Phonotephrite, $R=$ Rhyolite, $T=$ Trachyte, $T A=$ Trachyandesite, $T B=$ Trachybasalt,$T D=$ Trachydacite, $T E P=$ Tephrite, and $T P H=$ Tephriphonolite. 
al. (2012); Watts et al. (2011); Zaitsev et al. (2012); Zellmer and Turner(2007); Zellmer et al. (2000); Zhang et al. (2003); Zongfeng et al. (2009); and Zou et al. (2003, 2008).

IgRoCS automatically classified all samples and assigned appropriate IUGS rock names to them. The resulting TAS diagram is presented in Fig. 2. The choice of samples confirmed that all rock types were represented in this example file (DataChem_IUGS.xls).

IgRoCS can automatically process any number of samples in a single run, which is an advantage over SINCLAS when one is interested in processing large databases. IgRoCS, therefore, provides an unparallel advantage for the IUGS igneous rock classification as compared to all existing computer programs. IgRoCS is available on request to any of the authors.

\section{Conclusions}

Several computer programs, viz., WINROCK, IUGSTAS, SINCLAS, IgPet, GCDKit, PetroGraph, and IgRoCS, are available specifically for the IUGS classification and nomenclature of igneous rocks, of which IgRoCS presented in this paper seems to be the most versatile and useful program for strictly following the IUGS recommendations. WINROCK and IgPet are commercial software, whereas IUGSTAS, SINCLAS, GCDKit, PetroGraph, and IgRoCS are freely available.

\section{Acknowledgements}

We gratefully acknowledge a minor nomenclature error in the output of SINCLAS software kindly pointed out by Huang Jinxiang, which we corrected in the IgRoCS program. We also thank Alfredo Quiroz-Ruiz for maintaining the internet availability of the SINCLAS and IgRoCS programs.

\section{References}

Abdel-Rahman, A.-F.M., and Lease, N.A., 2011, Petrogenesis of Cenozoic mafic-ultramafic alkaline lavas from the Tigris volcanic field, NE Syria: Geological Magazine, v. 149, no. 1, pp. 1-18.

Agostini, S. 2003. Il magmatismo post-collisionale dell'anatolia occidentale: caratteri geochimici e petrologici, distribuzione spazio-temporale, quadro geodinamico. Ph.D. thesis. Università di Pisa, Pisa. 269 pp.

Agostini, S., Corti, G., Doglioni, C., Carminati, E., Innocenti, F., Tonarini, S., Manetti, P., Di Vincenzo, G., and Montanari, D., 2006, Tectonic and magmatic evolution of the active volcanic front in El Salvador: insight into the Berlín and Ahuachapán geothermal areas: Geothermics, v. 35, no. 4 , pp. 368-408.

Agostini, S., Doglioni, C., Innocenti, F., Manetti, P., Tonarini, S., and Savascin, M.Y., 2007, The transition from suductiion-related to intraplate Neogene magmatism in the Western Anatolia and Aegean area, in Beccaluva, L., Bianchini, M., and Wilson, M., eds, Cenozoic volcanism in the Mediterranean Area: Boulder, Colorado, Geolocial Society of America, pp. 1-15.

Agostini, S., Torçaer, M., and Savasçin, M.Y., 2010, Volcanic rocks from Foça-Karaburun and Ayvalik-Lesvos grabens (western Anatolia) and their petrogenetic-geodynamic significance: Turkish Journal of Earth Sciences, v. 19 , no. 2 , pp. $157-84$

Aguirre-Díaz, G.J., and McDowell, F.W., 2000, Volcanic evolution of the Amealco caldera, Central Mexico, in Delgado-Granados, H., AguirreDíaz, G., and Stock, J.M., eds, Cenozoic tectonics and volcanism of Mexico, GSA, pp. 179-93.

Agustín-Flores, J., Siebe, C., and Guilbaud, M.-N., 2011, Geology and geochemistry of Pelagatos, Cerro del Agua, and Dos Cerros monogenetic volcanoes in the Sierra Chichinautzin Volcanic Field, south of México City: Journal of Volcanology and Geothermal Research, v. 201, no. 1-4, pp. 143-62.

Ahmad, T., Tanaka, T., Sachan, H.K., Asahara, Y., Islam, R., and Khanna,
P.P., 2008, Geochemical and isotopic constraints on the age and origin of the Nidar Ophiolitic Complex, Ladakh India: implications for the NeoTethyan subduction along the Indus suture zone: Tectonophysics, v. 451, no. 1-4, pp. 206-24.

Ahmadian, J., Haschke, M., McDonald, I., Regelous, M., Ghorbani, M.R., Emami, M.H., and Murata, M., 2009, High magmatic flux during AlpineHimalayan collision:constraints from the Kal-e-Kafi complex, central Iran: Geological Society of America Bulletin, v. 121, no. 5/6, pp. $857-$ 68.

Aitchison, J., 1986, The statistical analysis of compositional data: London, New York, Chapman and Hall, 416 pp.

Akal, C., 2003, Mineralogy and geochemistry of melilite leucitites, Balcikhisar, Afyon (Turkey): Turkish Journal of Earth Sciences, v. 12, no. 3, pp. 215-39.

Alam, M.A., Chandrasekharam, D., Vaselli, O., Capaccioni, B., Manetti, P., and Santo, P.B., 2004, Petrology of the prehistoric lavas and dyke of the Barren island, Andaman sea, Indian ocean: Proceedings of the Indian Academy of Sciences (Earth and Planetary Sciences), v. 113, no. Special Issue, pp. 715-22.

Albrecht, A., and Goldstein, S.L., 2000, Effects of basement composition and age on silicic magmas across an accreted terrane-Precambrian crust boundary, Sierra Madre Occidental, Mexico: Journal of South American Earth Sciences, v. 13, no. 3, pp. 255-73.

Aldanmaz, E., Pearce, J.A., Thirlwall, M.F., and Mitchell, J.G., 2000, Petrogenetic evolution of late Cenozoic, post-collision volcanism in western Anatolia, Turkey: Journal of Volcanology and Geothermal Research, v. 102, no. 1-2, pp. 67-95.

Aldanmaz, E., Köprübasi, N., Gürer, Ö.F., Kaymakci, N., and Gourgaud, A., 2006, Geochemical constraints on the Cenozoic, OIB-type alkaline volcanic rocks of NW Turkey: Implications for mantle sources and melting processes: Lithos, v. 86, no. 1, pp. 50-76.

Aldanmaz, E., Yaliniz, M.K., Guctekin, A., and Goncuoglu, M.C., 2008, Geochemical characteristics of mafic lavas from the Neotethyan ophiolites in western Turkey: implications fro heterogeneous source contribution during variable stages of ocean crust generation: Geological Magazine, v. 145 , no. 1 , pp. $37-54$

Alici, P., Temel, A., and Gourgaud, A., 2002, Pb-Nd-Sr isotope and trace element geochemistry of Quaternary extension-related alkaline volcanism: a case study of Kula region (western, Turkey): Journal of Volcanology and Geothermal Research, v. 115, no. 3-4, pp. 487-510.

Altherr, R., Meyer, H.-P., Holl, A., Volker, F., Alibert, C., McCulloch, M.T., Majer, V., and . 2004, Geochemical and $\mathrm{Sr}-\mathrm{Nd}-\mathrm{Pb}$ isotopic characteristics of Late Cenozoic leucite lamproites from the East European Alpine belt (Macedonia and Yugoslavia): Contributions to Mineralogy and Petrology, v. 147 , no. 1 , pp. $58-73$.

Antunes, I.M.H.R., Neiva, A.M.R., Silva, M.M.V.G., and Corfu, F., 2009, The genesis of I- and S-type granitoid rocks of the Early Ordovician Oledo pluton, central Iberian zone (central Portugal): Lithos, v. 111, no. 3-4, pp. 168-85.

Arce, J.L., Macías, R., García Palomo, A., Capra, L., Macías, J.L., Layer, P., and Rueda, H., 2008, Late Pleistocene flank collapse of Zempoala volcano (central Mexico) and the role of fault reactivation: Journal of Volcanology and Geothermal Research, v. 177, no. 4, pp. 944-58.

Arnórsson, S., Gunnarsson, I., Stefánsson, A., Andrésdóttir, A., and Sveinbjörnsdóttir, A.E., 2002, Major element chemistry of surface- and ground waters in basaltic terrain, N-Iceland. I. Primary mineral saturation: Geochimica et Cosmochimica Acta, v. 66, no. 23, pp. 4015-46.

Arpa, M.C.B., Patino, L.C., and Vogel, T.A., 2008, The basaltic to trachydacitic upper Diliman tuff in Manila: petrogenesis and comparison with deposits from Taal and Laguna calderas: Journal of Volcanology and Geothermal Research, v. 177 , no. 4, pp. 1020-34.

Avanzinelli, R., Elliott, T., Tommasini, S., and Conticelli, S., 2008, Constraints on the genesis of potassium-rich Italian volcanic rocks from U/Th disequilibrium: Journal of Petrology, v. 49, no. 2, pp. 195-223.

Avellán, D.R., Macías, J.L., Pardo, N., Scolamacchia, T., and Rodriguez, D., 2012, Stratigraphy, geomorphology, geochemistry and hazard implications of the Nejapa Volcanic Field, western Managua, Nicaragua: Journal of Volcanology and Geothermal Research, v. 213-214, no., pp. $51-71$.

Ayabe, M., Takanashi, K., Shuto, K., Ishimoto, H., and Kawabata, H., 2012, Petrology and geochemistry of adakitic dacites and high- $\mathrm{MgO}$ andesites, and related calc-alkaline aacites from the miocene Okoppe volcanic field, N Hokkaido, Japan: Journal of Petrology, v. 53, no. 3, pp. 547-88.

Ayalew, D., Ebinger, C., Bourdon, E., Wolfenden, E., Yirgu, G., and Grassineau, N., 2006, Temporal compositional variation of syn-rift 
rhyolites along the western margin of the southern Red Sea and northern Main Ethiopian Rift, in Yirgu, G., Ebinger, C., and Maguire, P.K.H., eds, The Afar Volcanic Province within the East African Rift system.: London, Geological Society of London Special Publications, pp. 121-30.

Aydar, E., Bayhan, H., and Gourgaud, A., 2003, The lamprophyres of Afyon stratovolcano, western Anatolia, Turkey: description and genesis: Comptes Rendus Geoscience, v. 335, no. 3, pp. 279-88.

Aydin, F., Karsli, O., and Chen, B., 2008, Petrogenesis of the Neogene alkaline volcanics with implications for post-collisional lithospheric thinning of the Eastern Pontides, NE Turkey: Journal of Volcanology and Geothermal Research, v. 104, no. 1-4, pp. 249-66.

Bachmann, O., Dungan, M.A., and Lipman, P.W., 2002, The Fish Canyon magma body, San Juan volcanic field, Colorado: rejuvenation and eruption of an upper-crustal batholith: Journal of Petrology, v. 43, no. 8, pp. 1469-503.

Bagci, U., Parlak, O., and Höck, V., 2008, Geochemistry and tectonic environment of diverse magma generations forming the crustal units of the Kizildag (Hatay) ophiolite, southern Turkey: Turkish Journal of Earth Sciences, v. 17, no. 1, pp. 43-71.

Bailey, J.C., Jensen, E.S., Hansen, A., Kann, A.D.J., and Kann, K., 2009, Formation of heterogeneous magmatic series beneath North Santorini, South Aegean island arc: Lithos, v. 110, no. 1-4, pp. 20-36.

Ban, M., Hirotani, S., Wako, A., Suga, T., Iai, Y., Kagashima, S.-i., Shuto, K., and Kagami, H., 2007, Origin of felsic magmas in a large-caldera-related stratovolcano in the central part of NE Japan - petrogenesis of the Takamatsu volcano: Journal of Volcanology and Geothermal Research, igrocs, v. 167, no. 1-4, pp. 100-18.

Barker, A.K., Holm, P.M., Peate, D.W., and Barker, J.A., 2009, Geochemical stratigraphy of submarine lavas (3-5 Ma) from the Flamengos valley, Santiago, southern Cape Verde Islands: Journal of Petrology, v. 50, no. 1, pp. 169-93

Barling, J., Goldstein, S.L., and Nicholls, I.A., 1994, Geochemistry of Heard Island (Southern Indian Ocean): characterization of an enriched mantle component and implication for enrichment of the Sub-Indian ocean mantle: Journal of Petrology, v. 35, no. 4, pp. 1017-53.

Barrat, J.A., Joron, J.L., Taylor, R.N., Fourcade, S., Nesbitt, R.W., and Jahn, B.M., 2003, Geochemistry of basalts from Manda Hararo, Ethiopia: LREE-depleted basalts in Central Afar: Lithos, v. 69, no. 1-2, pp. 1-13.

Bayat, F., and Torabi, G., 2011, Alkaline lamprophyric province of Central Iran: Island Arc, v. 20, no. 3, pp. 386-400.

Beard, J.S., Lofgren, G.E., Sinha, A.K., and Tollo, R.P., 1994, Partial melting of apatite-bearing charnockite, granulite, and diorite: melt compositions, restite mineralogy, and petrologic implications: Journal of Geophysical Research, v. 99, no. B11, pp. 21591-603.

Beccaluva, L., Coltorti, M., Girolamo, P.D., Milani, L., Morra, V., and Siena, F., 2002, Petrogenesis and evolution of Mt. Vulture alkaline volcanism (Southern Italy): Mineralogy and Petrology, v. 74, no. 2-4, pp. 277-97.

Beccaluva, L., Bianchini, G., Natali, C., and Siena, F., 2009, Continental flood basalts and mantle plumes: a sase study of the Northern Ethiopian plateau: Journal of Petrology, v. 50, no. 7, pp. 1377-403.

Becker, M., and Le Roex, A.P., 2006, Geochemistry of South African on- and off-craton, Group I and Group II kimberlites: petrogenesis and source region evolution: Journal of Petrology, v. 47, no. 4, pp. 673-703.

Beier, C., Haase, K.M., and Hansteen, T.H., 2006, Magma evolution of the Sete Cidades volcano, São Miguel, Azores: Journal of Petrology, v. 47, no. 7, pp. 1375-411.

Beier, C., Haase, K., Abouchami, W., Krienitz, M.-S., and Hauff, F., 2008, Magma genesis by rifting of oceanic lithosphere above anomalous mantle: Terceira Rift, Azores: Geochemistry Geophysics Geosystems, v. 9, no. 12 , pp. 1-26.

Bellezza, M., Merlino, S., and Perchiazzi, N., 2004, Chemical and structural study of the Zr,Ti-disilicates in the venanzite from Pian di Celle, Umbria, Italy: European Journal of Mineralogy, v. 16, no. 6, pp. 957-69.

Benoit, M., Robles, A.A., Calmus, T., Maury, R.C., Bellon , H., Cotten, J., J., B., and Michaud, F., 2002, Geochemical Diversity of Late Miocene Volcanism in Southern Baja California, México: Implication of Mantle and Crustal Sources during the Opening of an Asthenospheric Window: Journal of Geology, v. 110, no. 6, pp. 627-48.

Bergmanis, E.C., Sinton, J.M., and Trusdell, F.A., 2000, Rejuvenated volcanism along the southwest rift zone, East Maui, Hawaii: Bulletin Volcanologique, v. 62, no. 4-5, pp. 239-55.

Blatter, D.L., and Hammersley, L., 2010, Impact of the Orozco Fracture Zone on the Central Mexican Volcanic Belt: Journal of Volcanology and Geothermal Research, v. 197, no. 1-4, pp. 67-84.

Blatter, D.L., Carmichael, I.S.E., Deino, A.L., and Renne, P.R., 2001, Neogene volcanism at the front of the central Mexican volcanic belt: basaltic andesites to dacites, with contemporaneous shoshonites and high-TiO2 lava: Geological Society of America Bulletin, v. 113, no. 10, pp. 132442.

Blatter, D.L., Farmer, G.L., and Carmichael, I.S.E., 2007, A north-south transect across the Central Mexican Volcanic Belt at $\sim 100^{\circ} \mathrm{W}$ : spatial distribution, petrological, geochemical, and isotopic characteristics of Quaternary volcanism: Journal of Petrology, v. 48, no. 5, pp. 901-50.

Boari, E., Tommasini, S., Laurenzi, M.A., and Conticelli, S., 2009, Transition from ultrapotassic kamafugitic to sub-alkaline magmas: $\mathrm{Sr}, \mathrm{Nd}$, and $\mathrm{Pb}$ isotope, trace element and 40Ar-39Ar age data from the Middle Latin Valley volcanic field, Roman Magmatic Province, Central Italy: Austrian Journal of Earth Sciences, v. 100, no. 7, pp. 54-64.

Bolge, L.L., Carr, M.J., Feigenson, M.D., and Alvarado, G.E., 2006, Geochemical stratigraphy and magmatic evolution at Arenal volcano, Costa Rica: Journal of Volcanology and Geothermal Research, v. 157, no. $1-3$, pp. $34-48$.

Booden, M.A., Smith, I.E.M., Black, P.M., and Mauk, J.L., 2011, Geochemistry of the Early Miocene volcanic succession of Northland, New Zealand, and implications for the evolution of subduction in the Southwest Pacific: Journal of Volcanology and Geothermal Research, v. 199, no. 1-2, pp. 25-37.

Booden, M.A., Smith, I.E.M., Mauk, J.L., and Black, P.M., 2012, Geochemical and isotopic development of the Coromandel volcanic zone, northern New Zealand, since 18 Ma: Journal of Volcanology and Geothermal Research, v. 219-220, no., pp. 15-32.

Bruni, S., D’Orazio, M., Haller, M.J., Innocenti, F., Manetti, P., Pécskay, Z., and Tonarini, S., 2008, Time-evolution of magma sources in a continental back-arc setting: the Cenozoic basalts from Sierra de San Bernardo (Patagonia, Chubut, Argentina): Geological Magazine, v. 145, no. 5, pp. 714-732.

Bryan, S., E., 2006, Petrology and geochemistry of the Quaternary calderaforming, phonolitic granadilla eruption, Tenerife (Canary Islands): Journal of Petrology, v. 47, no. 8, pp. 1557-89.

Bryant, J.A., Yogodzinski, G.M., Hall, M.L., Lewicki, J.L., and Bailey, D.G., 2006, Geochemical constraints on the origin of volcanic rocks from the Andean Northern volcanic zone, Ecuador: Journal of Petrology, v. 47, no. 6 , pp. 1147-75.

Cadoux, A., and Pinti, D.L., 2009, Hybrid character and pre-eruptive events of Mt Amiata volcano (Italy) inferred from geochronological petrogeochemical and isotopic data: Journal of Volcanology and Geothermal Research, v. 179, no. 3-4, pp. 169-90.

Calmus, T., Aguillón-Robles, A., Maury, R.C., Bellon , H., Benoit, M., Cotten, J., Bourgois, J., and Michaud, F., 2003, Spatial and temporal evolution of basalts and magnesian andesites ("Bajaites") from Baja California, Mexico: the role of slab melts: Lithos, v. 66, no. 1-2, pp. 77-105.

Calmus, T., Pallares, C., Maury, R.C., Robles, A.A., Bellon, H., Benoit, M., and Michaud, F., 2010, Volcanic markers of the post-subduction evolution of Baja California and Sonora, Mexico: slab tearing versus lithospheric rupture of the Gulf of California: Pure and Applied Geophysics, v. 168, no. 8-9, pp. 1303-30.

Carmichael, I.S.E., Frey, H.M., Lange, R.A., and Hall, C.M., 2006, The Pleistocene cinder cones surrounding Volcán Colima, Mexico re-visited: eruption ages and volumes, oxidation states, and sulfur content: Bulletin of Volcanology, v. 68, no. 5, pp. 407-419.

Carn, S.A., and Pyle, D.M., 2001, Petrology and geochemistry of the Lamongan volcanic field, East Java, Indonesia: primitive Sunda Arc magmas in an extensional tectonic setting?: Journal of Petrology, v. 42, no. 9 , pp. $1643-83$.

Carr, M., 1995, Program IgPet: Somerset, NJ, Terra Softa, Inc.

Carrasco-Núñez, G., Siebert, L., Díaz-Castellón, R., Vázquez-Selem, L., and Capra, L., 2010, Evolution and hazards of a long-quiescent compound shield-like volcano: Cofre de Perote, Eastern Trans-Mexican Volcanic Belt: Journal of Volcanology and Geothermal Research, v. 197, no. 1-4, pp. 209-24.

Chadwick, J.P., Troll., V.R., Ginibre., R.G., Morgan., D., Gertisser, R., Waight, T.E., and Davidson, J.P., 2007, Carbonate assimilation at Merapi Volcano, Java, Indonesia: insights from crystal isotope stratigraphy: Journal of Petrology, v. 48, no. 9, pp. 1793-812.

Chakrabarti, R., Basu, A.R., Santo, A.P., Tedesco, D., and Vaselli, O., 2009, Isotopic and geochemical evidence for a hetrogeneous mantle plume origin of the Virunga volcanics, Western rift, East African Rift system: Chemical Geology, v. 259, no. 3-4, pp. 273-89.

Chang, J.M., Feeley, T.C., and Deraps, M.R., 2009, Petrogenesis of basaltic volcanic rocks from the Pribilof Islands, Alaska, by melting of 
metasomatically enriched depleted lithosphere, crystallization differentiation, and magma mixing: Journal of Petrology, v. 50, no. 12, pp. 2249-86.

Chayes, F., 1960, On correlation between variables of constant sum: Journal of Geophysical Research, v. 65, no. 12, pp. 4185-4193.

Chen, J.-L., Zhao, W.-X., Xu, J.-F., Wang, B.-D., and Kang, Z.-Q., 2012, Geochemistry of Miocene trachytes in Bugasi, Lhasa block, Tibetan Plateau: mixing products between mantle- and crust-derived melts?: Gondwana Research, v. 21, no. 1, pp. 112-22.

Churikova, T., Dorendorf, F., and Wörner, G., 2001, Sources and fluids in the mantle wedge below Kamchatka, evidence from across-arc geochemical variation: Journal of Petrology, v. 42, no. 8, pp. 1567-93.

Conly, A.G., Brenan, J.M., Bellon, H., and Scott, S.D., 2005, Arc to rift transitional volcanism in the Santa Rosalía region, Baja California Sur, Mexico: Journal of Volcanology and Geothermal Research, v. 142, no. 3-4, pp. 303-41.

Conticelli, S., Guarnieri, L., Farinelli, A., Mattei, M., Avanzinelli, R., Bianchini, G., Boari, E., Tommasini, S., Tiepolo, M., Prelevic, D., and Venturelli, G., 2009, Trace elements and $\mathrm{Sr}-\mathrm{Nd}-\mathrm{Pb}$ isotopes of $\mathrm{K}$-rich, shoshonitic, and calc-alkaline magmatism of the Western Mediterranean Region: genesis of ultrapotassic to calc-alkaline magmatic associations in a post-collisional geodynamic setting: Lithos, v. 107, no. 1-2, pp. 68-92.

Coogan, L.A., MacLeod, C.J., Dick, H.J.B., Edwards, S.J., Kvassnes, A., Natland, J.H., Robinson, P.T., Thompson, G., and O'Hara, M.J., 2001, Whole-rock geochemistry of gabbros from the Southwest Indian Ridge: constraints on geochemical fractionations between the upper and lower oceanic crust and magma chamber processes at (very) slow-spreading ridges: Chemical Geology, v. 178, no. 1, pp. 1-22.

Corgne, A., Maury, R.C., Lagabrielle, Y., Bourgois, J., Suarez, M., Cotten, J., and Bellon, H., 2001, La diversité des basalts de Patagonie à la latitude du point triple du Chili $\left(46^{\circ}-47^{\circ}\right.$ lat. S): doneées complémentaires et implications sur les conditions de la subduction: Comptes Rendus de L Academie des Sciences du Paris/Earth and Planetary Sciences, v. 333, no. 7, pp. 363-71.

Cousens, B.L., Clague A., D., and Sharp, W.D., 2003, Chronology, chemistry and origin of trachytes from Hualalai volcano, Hawaii: Geochemistry Geophysics Geosystems, v. 4, no. 9, pp. 1078, doi: 10.29/2003GC000560.

Cox, K.G., Bell, J.D., and Pankhurst, R.J., 1979, The interpretation of igneous rocks: London, George Allen \& Unwin, 450 pp.

Cross, W., Iddings, J.P., Pirsson, L.V., and Washington, H.S., 1902, A quantitative chemico-mineralogical classification and nomenclature of igneous rocks: Journal of Geology, v. 10, no. 6, pp. 555-690.

Çubukçu, H.E., Ulusoy, I., Aydar, E., Ersoy, O., Sen, E., Gourgaud, A., and Guillou, H., 2012, Mt. Nemrut volcano (Eastern Turkey): temporal petrological evolution: Journal of Volcanology and Geothermal Research, v. 209-210, no., pp. 33-60.

Cucciniello, C., Melluso, L., Morra, V., Storey, M., Rocco, I., Franciosi, L., Grifa, C., Petrone, C.M., and Vincent, M., 2011, New 40Ar-39Ar ages and petrogenesis of the Massif d'Ambre volcano, northern Madagascar, in L., B., Bianchini, G., and Wison, M., eds, Volcanism and evolution of the African lithosphere: Boulder, Colorado, Geological Society of America Special Paper, pp. 257-81.

Cunningham, H.S., Turner, S.P., Patia, A.D., Eggins, S.M., and Arculus, R.J., 2009, Temporal variations in U-series disequilibria in an active caldera, Rabaul, Papua New Guinea: Journal of Petrology, v. 50, no. 3, pp. 507-29.

de Lima, E.F., Machado, A., Nardi, L.V.S., Saldanha, D.L., Azevedo, J.M.M., Sommer, C.A., Waichel, B.L., Chemale Jr., F., and de Almeida, D.P.M., 2011, Geochemical evidence concerning sources and petrologic evolution of Faial Island, Central Azores: International Geology Review, v. 53, no. 14 , pp. 1684-708.

Deering, C.D., Bachmann, O., Dufek, J., and Gravley, D.M., 2011, Rift-related transition from andesite to rhyolite volcanism in theTaupo Volcanic Zone (New Zealand) controlled by crystal-melt dynamics in mush zones with variable mineral assemblages: Journal of Petrology, v. 52, no. 11, pp. 2243-63.

Deering, C.D., Vogel, T.A., Patino, L.C., Szymanski, D.W., and Alvarado, G.E., 2012, Magmatic processes that generate chemically distinct silicic magmas in NW Costa Rica and the evolution of juvenile continental crust in oceanic arcs: Contributions to Mineralogy and Petrology, v. 163, no. 2, pp. 259-75.

Dilek, Y., Imamverdiyev, N., and Altunkaynak, S., 2010, Geochemistry and tectonics of Cenozoic volcanism in the Lesser Caucasus (Azerbaijan) and the peri-Arabian region: collision-induced mantle dynamics and its magmatic fingerprint: International Geology Review, v. 52, no. 4-6, pp. 536-78.
Ding, L., Kapp, P., Zhong, D., and Deng, W., 2003, Cenozoic volcanism in Tibet: evidence for a transition from oceanic to continental subduction: Journal of Petrology, v. 44, no. 10, pp. 1833-65.

Dini, A., Innocenti, F., Rocchi, S., Tonarini, S., and Westerman, D.S., 2002, The magmatic evolution of the late Miocene laccolith-pluton-dyke granitic complex of Elba Island, Italy: Geological Magazine, v. 139, no. 3, pp. 257-79.

Doucelance, R., Escrig, S., Moreira, M., Gariépy, C., and Kurz, M.D., 2003, $\mathrm{Pb}-\mathrm{Sr}-\mathrm{He}$ isotope and trace element geochemistry of the Cape Verde archipelago: Geochimica et Cosmochimica Acta, v. 67, no. 19, pp. 371733.

Dunworth, E.A., and Bell, K., 1998, Melilitolites: a new scheme of classification: Canadian Mineralogist, v. 36, no. 3, pp. 895-903.

Dunworth, E.A., and Wilson, M., 1998, Olivine melilitites of the SW German Tertiary volcanic province: mineralogy and petrogenesis: Journal of Petrology, v. 39, no. 10, pp. 1805-36.

Elburg, M.A., van Leeuwen, T., Foden, J., and Muhardjo, 2003, Spatial and temporal isotopic domains of contrasting igneous suites in Western and Northern Sulawesi, Indonesia: Chemical Geology, v. 199, no. 3-4, pp. 243-76.

Elitok, Ö., Özgür, N., Drüppel, K., Dilek, Y., Platevoet, B., Guillou, H., Poisson, A., Scaillet, S., Satir, M., and Siebel, W., 2010, Origin and geodynamic evolution of late Cenozoic potassium-rich volcanism in the Isparta area, southwestern Turkey: International Geology Review, v. 52, no. 4-6, pp. 454-504.

Ferlito, C., Coltorti, M., Cristofolini, R., and Giacomoni, P.P., 2009, The contemporaneous emission of low-K and high-K trachybasalts and the role of the NE Rift during the 2002 eruptive event, Mt. Etna, Italy: Bulletin of Volcanology, v. 71, no. 5, pp. 575-87.

Fontijn, K., Ernst, G.G.J., Elburg, M.A., Williamson, D., Abdallah, E., Kwelwa, S., Mbede, E., and Jacobs, P., 2010, Holocene explosive eruptions in the Rungwe Volcanic Province, Tanzania: Journal of Volcanology and Geothermal Research, v. 196, no. 1-2, pp. 91-110.

Fretzdorff, S., and Haase, K.M., 2002, Geochemistry and petrology of lavas from the submarine flanks of Réunion Island (western Indian Ocean) implications for magma genesis and the mantle source: Mineralogy and Petrology, v. 75, no. 3-4, pp. 153-84.

Frey, F.A., Weis, D., Yang, H.-J., Nocolaysen, K., Leyrit, H., and Giret, A. 2000, Temporal geochemical trends in Kerguelen Archipelago basalts: evidence for decreasing magma supply from the Kerguelen plume: Chemical Geology, v. 164, no. 1, pp. 61-80.

Gao, Y., Yang, Z., Santosh, M., Hao, Z., Wei, R., and Tian, S., 2010, Adakitic rocks from slab melt-modified mantle sources in the continental collision zone of southern Tibet: Lithos, v. 119, no. 3-4, pp. 651-63.

García Tovar, G.P. 2009. Caracterización geología, geoquímica e isotópica de las lavas del estratovolcán Telepón, Sierra Nevada, México. MS thesis. Universidad Nacional Autónoma de México, México, D.F. 118 pp.

Geldmacher J., and Hoernle, K., 2000, The 72 Ma geochemical evolution of the Madeira hotspot (eastern North Atlantic): recycling of Paleozoic $(\leq 500 \mathrm{Ma})$ oceanic lithosphere: Earth and Planetary Science Letters, v. 183 , no. $1-2$, pp. $73-92$.

Gomes, M.E.P., and Neiva, A.M.R., 2005, Geochemistry of granitoids and their minerals from Rebordelo-Agrochão area, northern Portugal: Lithos, v. 81 , no. $1-4$, pp. 235-54.

Gorring, M.L., and Kay, S.M., 2001, Mantle processes and sources of Neogene slab window magmas from southern Patagonia, Argentina: Journal of Petrology, v. 42, no. 6, pp. 1067-94.

Guzman, S., Petrinovic, I.A., Brod, J.A., Hongn, F.D., Seggiaro, R.E., Montero, C., Carniel, R., Dantas, E.L., and Sudo, M., 2011, Petrology of the Luingo caldera (SE margin of the Puna plateau): A middle Miocene window of the arc-back arc configuration: Journal of Volcanology and Geothermal Research, v. 200, no. 3-4, pp. 171-91.

Haase, K.M., Worthington, T.J., Stoffers, P., Garbe-Schönberg, D., and Wright, I., 2002, Mantle dynamics, element recycling, and magma genesis beneath the Kermadec arc-Havre Trough: Geochemistry Geophysics Geosystems, v. 3 , no. 11 , pp. 1071, doi:10.29/2002GC00035.

Haase, K.M., Goldschmidt, B., and Garbe-Schönberg, C.-D., 2004, Petrogenesis of Tertiary continental intra-plate lavas from the Westerwald region, Germany: Journal of petrology, v. 45, no. 5, pp. 883-905.

Hanyu, T., Tatsumi, Y., Senda, R., Miyazaki, T., Chang, Q., Hirahara, Y., Takahashi, T., Kawabata, H., and Suzuki, K., 2011, Geochemical characteristics and origin of the HIMU reservoir: A possible mantle plume source in the lower mantle: Geochemistry Geophysics Geosystems, v. 12 , no. 2 , pp. 1-30.

Harper, G.D., 2003, Tectonic implications of boninite, arc tholeiite, and MORB 
magma types in the Josephine ophiolite, California-Oregon, in Dilek, Y., and Robinson, P.T., eds, Ophiolites in Earth History: Bath, U.K., Geological Society of London, pp. 207-30.

Hawkins, J.W., and Ishizuka, O., 2009, Petrologic evolution of Palau, a nascent island arc: Island Arc, v. 18, no. 4, pp. 599-641.

Hekinian, R., Cheminée, J.L., Dubois, J., Stoffers, P., Scott, S., Guivel, C., Garbe-Schönberg, D., Devey, C., Bourdon, B., Lackschewitz, K., McMurtry, G., and Le Drezen, E., 2003, The Pitcairn hotspot in the South Pacific: distribution and composition of submarine volcanic sequences: Journal of Volcanology and Geothermal Research, v. 121, no. 3-4, pp. 219-45.

Hoke, L., and Lamb, S., 2007, Cenozoic behind-arc volanism in the Bolivian Andes, South America: implications for mantle melt generation and lithospheric structure: Journal of Geological Society London, v. 164, no. 4, pp. 795-814.

Holm, P.M., Wilson, J.R., Christensen, B.P., Hansen, L., Hansen, S.L., Hein, K.M., Mortensen, A.K., Pedersen, R., Plesner, S., and Runge, M.K., 2006, Sampling the Cape Verde mantle plume: evolution of melt compositions on Santo Antão, Cape Verde Islands: Journal of Petrology, v. 47, no. 1, pp. 145-89.

Horz, K.H., Worthington, T.J., Winn, K., and Stoffers, P., 2004, Late Quaternary tephra in the New Ireland basin, Papua New Guinea: Journal of Volcanology and Geothermal Research, v. 132, no. 1, pp. 73-95.

Hou, Z.-Q., Gao, Y.-F., Qu, X.-M., Rui, Z.-Y., and Mo, X.-X., 2004, Origin of adakitic intrusives generated during mid-Miocene east-west extension in southern Tibet: Earth and Planetary Science Letters, v. 220, no. 1-2, pp. 139-55.

Houzar, S., and Novák, M., 2002, Marbles with carbonatite-like geochemical signature from variegated units of the Bohemian massif, Czech Republic, and their geological significance: Journal of the Czech Geological Society, v. 47 , no. $3-4$, pp. $103-10$

Howarth, G.H., Michael, E., Skinner, W., and Prevec, S.A., 2011, Petrology of the hypabyssal kimberlite of the Kroonstad group II kimberlite (orangeite) cluster, South Africa: Evolution of the magma within the cluster: Lithos, v. 125, no. 1-2, pp. 795-808.

Hsu, C.-N., Chen, J.-C., and Ho, K.-S., 2000, Geochemistry of Cenozoic volcanic rocks from Kirin Province, northeast China: Geochemical Journal, v. 34, no. 1, pp. 33-58.

Ilbeyli, N., Pearce, J.A., Thirlwall, M.F., and Mitchell, J.G., 2004, Petrogenesis of collision-related plutonics in Central Anatolia, Turkey: Lithos, v. 72, no. 3-4, pp. 163-82.

Ireland, T.J., Walker, R.J., and Garcia, M.O., 2009, Highly siderophile elements and 187Os isotope systematics of Hawaiian picrites: Implications for parental melt composition and source heterogeneity: Chemical Geology, v. 260, no. 1-2, pp. 112-28.

Ishizuka, O., Yuasa, M., and Uto, K., 2002, Evidence of porphyry coppertype hydrothermal activity from a submerged remnant back-arc volcano of the Izu-Bonin arc Implications for the volcanotectonic history of backarc seamounts: Earth and Planetary Science Letters, v. 198, no. 3-4, pp. 381-99.

Janousek, V., Farrow, C.M., and Erban, V., 2006, Interpretation of wholerock geochemical data in igneous geochemistry: introducing Geochemical Data Toolkit (GCDkit): Journal of Petrology, v. 47, no. 6, pp. 1255-1259.

Janousek, V., Farrow, C. M., Erban, V., and Trubac, J., 2011, Brand new Geochemical Data Toolkit (GCDkit 3.0) - is it worth upgrading and browsing documentation? (Yes!): Geologicke vyzkumy na Morave a ve Slezsku, v. 18, no. 1, pp. 26-30.

Jian, P., Liu, D., Kroner, A., Zhang, Q., Wang, Y., Sun, X., and Zhang, W., 2009, Devonian to Permian plate tectonic cycle of the paleo-Tethys orogen in southwest China (I): Geochemistry of ophiolites, arc/back-arc assemblages and within-plate igneous rocks: Lithos, v. 113, no. 3-4, pp. 748-66.

Johannsen, A., 1931, A descriptive petrography of the igneous rocks. Vol. 1: Chicago, Chicago University Press, 267 pp.

Jørgensen, J.O., and Holm, P.M., 2002, Temporal variation and carbonatite contamination in primitive ocean island volcanics from São Vicente, Cape Verde islands: Chemical Geology, v. 192, no. 3-4, pp. 249-67.

Jutzeler, M., Schmincke, H.-U., and Sumita, M., 2010, The incrementally zoned Miocene Ayagaures ignimbrite (Gran Canaria, Canary Islands): Journal of Volcanology and Geothermal Research, v. 196, no. 1-2, pp. 1-19.

Karsli, O., Chen, B., Uysal, I., Aydin, F., Wijbrans, J.R., and Kandemir, R., 2008, Elemental and $\mathrm{Sr}-\mathrm{Nd}-\mathrm{Pb}$ isotopic geochemistry of the most recent Quaternary volcanism in the Erzincan basin, Eastern Turkey: framework for the evaluation of basalt-lower crust interaction: Lithos, v. 106, no. 12, pp. 55-70.
Kawabata, H., Hanyu, T., Chang, Q., Kimura, J.-I., Nichols, A.R.L., and Tatsumi, Y., 2011, The petrology and geochemistry of St. Helena alkali basalts: evaluation of the oceanic crust-recycling model for HIMU OIB: Journal of Petrology, v. 52, no. 4, pp. 791-838.

Kelsey, C.H., 1965, Calculation of the C.I.P.W. norm: Mineralogical Magazine, v. 34, no. , pp. 276-282.

Kerrich, R., and Manikyamba, C., 2012, Contemporaneous eruption of Nbenriched basalts - K-adakites - Na-adakites from the $2.7 \mathrm{Ga}$ Penakacherla terrane: implications for subduction zone processes and crustal growth in the eastern Dharwar craton, India: Canadian Journal of Earth Sciences, v. 49 , no. 4, pp. 615-36.

Kim, K.H., Nagao, K., Sumino, H., Tanaka, T., and Hayashi, T., 2008, He-Ar and $\mathrm{Nd}-\mathrm{Sr}$ isotopic compositions of late Pleistocene felsic plutonic back arc basin rocks from Ulleungdo volcanic island, South Korea: Implications for the genesis of young plutonic rocks in a back arc basin: Chemical Geology, v. 253, no. 3-4, pp. 183-95.

Kimura, J.-I., Tanji, T., Yoshida, T., and Iizumi, S., 2001, Geology and geochemistry of lavas at Nekoma volcano: implications for origin of Quaternary low-K andesite in the north-eastern Honshu arc, Japan: The Island Arc, v. 10, no. 2, pp. 116-34.

Koprubasi, N., and Aldanmaz, E., 2004, Geochemical constraints on the petrogenesis of Cenozoic I - type granitoids in Northwest Anatolia, Turkey: evidence for magma generation by lithospheric delamination in a postcollisional setting: International Geology Review, v. 46, no. 8, pp. $705-$ 29.

Krochert, J., and Buchner, E., 2009, Age distribution of cinder cones within the Bandas del Sur Formation, southern Tenerife, Canary Islands: Geological Magazine, v. 146, no. 2, pp. 161-72.

Le Bas, M.J., 1999, Sovite and alvikite; two chemically distinct calciocarbonatites C1 and C2: South African Journal of Geology, v. 102, no. 2, pp. 109-121.

Le Bas, M.J., 2000, IUGS reclassification of the high-Mg and picritic volcanic rocks: Journal of Petrology, v. 41, no. 10, pp. 1467-1470.

Le Bas, M.J., Le Maitre, R.W., Streckeisen, A., and Zanettin, B., 1986, A chemical classification of volcanic rocks based on the total alkali-silica diagram: Journal of Petrology, v. 27, no. 3, pp. 745-750.

Le Maitre, R.W., 1973, Experiences with CLAIR: a computer library of analysed igneous rocks. Chemical Geology, v. 12, no. , pp. 301-308.

Le Maitre, R.W., 1976a. Some problems of the projection of chemical data into mineralogical classifications: Contributions of Mineralogy and Petrology, v. 56, no. 1, pp. 181-189.

Le Maitre, R.W., 1976b. Chemical variability of some common igneous rocks. Jounal of Petrology, v. 17, no. , pp. 589-637.

Le Maitre (2002) Appendix C, in Le Maitre, R.W., Streckeisen, A., Zanettin, B., Le Bas, M.J., Bonin, B., Bateman, P., Bellieni, G., Dudek, A., Schmid, R., Sorensen, H., and Woolley, A.R., eds., Igneous rocks. A classification and glossary of terms: recommendations of the International Union of Geological Sciences Subcommission of the Systematics of Igneous Rocks: Second ed., Cambridge, Cambridge University Press, pp. 225-236.

Le Maitre, R.W., Streckeisen, A., Zanettin, B., Le Bas, M.J., Bonin, B., Bateman, P., Bellieni, G., Dudek, A., Schmid, R., Sorensen, H., and Woolley, A.R., 1989, Igneous rocks. A classification and glossary of terms: recommendations of the International Union of Geological Sciences Subcommission of the Systematics of Igneous Rocks: Oxford, Blackwell Scientific Publications, 193 pp.

Le Maitre, R.W., Streckeisen, A., Zanettin, B., Le Bas, M.J., Bonin, B., Bateman, P., Bellieni, G., Dudek, A., Schmid, R., Sorensen, H., and Woolley, A.R., 2002, Igneous rocks. A classification and glossary of terms: recommendations of the International Union of Geological Sciences Subcommission of the Systematics of Igneous Rocks: Second ed., Cambridge, Cambridge University Press, $236 \mathrm{pp}$.

Lloyd, F.E., Huntingdon, A.T., Davies, G.R., and Nixon, P.H., 1991, Phanerozoic volcanism of southern Uganda: a case for regional $\mathrm{K}$ and LILE enrichment of the lithosphere beneath a domed and rifted continental plate, in Kampunzu, A.B., and Lubala, R.T., eds, Magmatism in extensional structural settings: Berlin, Germany, Springer Verlag, pp. 23-72.

Ma, G.S.-K., Malpas, J., Xenophontos, C., and Chan, G.H.-N., 2011, Petrogenesis of latest Miocene-Quaternary continental intraplate volcanism along the northern dead sea fault system (Al Ghab-Homs Volcanic Field), Western Syria: Evidence for lithosphere-asthenosphere interaction: Journal of Petrology, v. 52, no. 2, pp. 401-30.

Mahéo, G., Blichert-Toft, J., Pin, C., Guillot, S., and Pecher, A., 2009, Partial melting of mantle and crustal sources beneath south Karakorum, Pakistan: implications for the Miocene geodynamic evolution of the India-Asia convergence zone: Journal of Petrology, v. 30, no. 3, pp. 427-49. 
Manikyamba, C., Naqvi, S.M., Rao, D.V.S., Mohan, M.R., Khanna, T.C., Rao, T.G., and Reddy, G.L.N., 2005, Boninites from the Neoarchaean Gadwal greenstone belt, Eastern Dharwar Craton, India: implications for Archaean subduction processes: Earth and Planetary Science Letters, v. 230 , no. $1-2$, pp. $65-83$.

Marshall, A.S., Macdonald, R., Rogers, N.W., Fitton, J.G., Tindle, A.G., Nejbert, K., and Hinton, R.W., 2009, Fractionation of peralkaline silicic magmas: the Greater Olkaria Volcanic Complex, Kenya Rift Valley: Journal of Petrology, v. 50, no. 2, pp. 323-59.

Martynov, A.Y., Kimura, J.-I., Martynov, Y.A., and Rybin, A.V., 2010, Geochemistry of late Cenozoic lavas on Kunashir Island, Kurile Arc: Island Arc, v. 19, no. 1, pp. 86-104.

Massaferro, G.I., Haller, M.J., D’Orazio, M., and Alric, V.I., 2006, Sub-recent volcanism in northern Patagonia: a tectonomagmatic approach: Journal of Volcanology and Geothermal Research, v. 155, no. 3-4, pp. 227-43.

Melluso, L., De'Genaro, R., and Rocco, I., 2010, Compositional variations of chromiferous spinel in Mg-rich rocks of the Deccan Traps, India: Journal of Earth System Science, v. 119, no. 3, pp. 343-63.

Middlemost, E.A.K., 1989. Iron oxidation ratios, norms and the classification of volcanic rocks: Chemical Geology, v. 77, no. 1, pp. 19-26.

Middlemost, E.A.K., 1994, Naming materials in the magma/igneous rock system: Earth Science Reviews, v. 37, no. 1, pp. 215-224.

Nikogosian, I., and van Bergen, M.J., 2010, Heterogeneous mantle sources of potassium-rich magmas in central-southern Italy: Melt inclusion evidence from Roccamonfina and Ernici (Mid Latina Valley): Journal of Volcanology and Geothermal Research, v. 197, no. 1-4, pp. 279-302.

Nonnotte, P., Benoit, M., Le Gall, B., Hémond, C., Rolet, J., and Cotten, J., 2011, Petrology and geochemistry of alkaline lava series, Kilimanjaro, Tanzania: new constraints on petrogenetic processes: Geological Society of America Special Paper, v. 478, no., pp. 127-58.

Ortiz-Hernández, L. E., Acevedo-Sandoval, O. A., and Flores-Castro, K., 2003, Early Cretaceous intraplate seamounts from Guanajuato, central Mexico: geochemical and mineralogical data: Revista Mexicana de Ciencias Geológicas, v. 20, p. 27-40.

Owen, J.P., 2008, Geochemistry of lamprophyres from the Western Alps, Italy: implications for the origin of an enriched isotopic component in the Italian mantle: Contributions to Mineralogy and Petrology, v. 155, no. 3, pp. 341-62.

Özdemir, Y., Blundy, J., and Gülec, N., 2011, The importance of fractional crystallization and magma mixing in controlling chemical differentiation at Süphan stratovolcano, eastern Anatolia, Turkey: Contributions to Mineralogy and Petrology, v. 162, no. 3, pp. 573-97.

Pappalardo, L., Ottolini, L., and Mastrolorenzo, G., 2008, The Campanian Ignimbrite (southern Italy) geochemical zoning: insight on the generation of a super-eruption from catastrophic differentiation and fast withdrawal: Contributions to Mineralogy and Petrology, v. 156, no. 1, pp. 1-6.

Patino, L.C., Velbel, M.A., Price, J.R., and Wade, J.A., 2003, Trace element mobility during spheroidal weathering of basalts and andesites in Hawaii and Guatemala: Chemical Geology, v. 202, no. 3-4, pp. 343-64.

Peccerillo, A., Barberio, M.R., Yirgu, G., Ayalew, D., Barbieri, M., and Wu, T.W., 2003, Relationships between mafic and peralkaline silicic magmatism in continental rift settings: a petrological, geochemical and isotopic study of the Gedemsa volcano, central Ethiopian rift: Journal of Petrology, v. 44, no. 11, pp. 2003-32.

Perini, G., Francalanci, L., Davidson, J.P., and Conticelli, S., 2004, Evolution and genesis of magmas from Vico volcano, central Italy: multiple differentiation pathways and variable parental magmas: Journal of Petrology, v. 45, no. 1, pp. 139-57.

Petrelli, M., Poli, G., Perugini, D., and Peccerillo, A., 2005, PetroGraph: A new software to visualize, model, and present geochemical data in igneous petrology: Geochemistry Geophysics Geosystems, v. 6, pp. doi.org/ 10.1029/2005GC000932

Polat, A., Hofmann, A.W., and Rosing, M.T., 2002, Boninite-like volcanic rocks in the 3.7-3.8 Ga Isua greenstone belt, West Greenland: geochemical evidence for intra-oceanic subduction zone processes in the early earth: Chemical Geology, v. 184, no. 3-4, pp. 231-54.

Price, R.C., Cooper, A.F., Woodhead, J.D., and Cartwright, I., 2003, Phonolitic diatremes within the Dunedin volcano, South Island, New Zealand: Journal of Petrology, v. 44, no. 11, pp. 2053-80.

Pruseth, K.L., 2009, Calculation of the CIPW norm: New formulas: Journal of Earth System Science, v. 118, no. 1, pp. 101-113

Ren, Z.-Y., Takahashi, E., Orihashi, Y., and Johnson, K.T.M., 2004, Petrogenesis of tholeiitic lavas from the submarine Hana ridge, Haleakala volcano, Hawaii: Journal of Petrology, v. 45, no. 10, pp. 2067-99.

Robin, C., Eissen, J.-P., Samaniego, P., Martin, H., Hall, M., and Cotten, J.,
2009, Evolution of the late Pleistocene Mojanda-Fuya Fuya volcanic complex (Ecuador), by progressive adakitic involvement in mantle magma sources: Bulletin of Volcanology, v. 71, no. 3, pp. 233-58.

Rogers, N.W., Evans, P.J., Blake, S., Scott, S.C., and Hawkesworth, C.J., 2004, Rates and timescales of fractional crystallization from 238U230Th-226Ra disequilibria in trachyte lavas from Longonot volcano, Kenya: Journal of Petrology, v. 45, no. 9, pp. 1747-76.

Rolland, Y., Galoyan, G., Bosch, D., Sosson, M., Corsini, M., Fornari, M., and Chrystèle, V., 2009, Jurassic back-arc and Cretaceous hot-spot series In the Armenian ophiolites - Implications for the obduction process: Lithos, v. 112, no. 3-4, pp. 163-87.

Rollinson, H. R., 1993, Using geochemical data: evaluation, presentation, interpretation: Essex, Longman Scientific Technical, 344 pp.

Rollinson, H., 2009, New models for the genesis of plagiogranites in the Oman ophiolite: Lithos, v. 112, no. 3-4, pp. 603-14.

Ronga, F., Lustrino, M., Marzoli, A., and Melluso, L., 2010, Petrogenesis of a basalt-comendite-pantellerite rock suite: the Boseti volcanic complex (Main Ethiopian Rift): Mineralogy and Petrology, v. 98, no. 1-4, pp. 227-43.

Rooney, T., Furman, T., Bastow, I., Ayalew, D., and Yirgu, G., 2007, Lithospheric modification during crustal extension in the Main Ethiopian Rift: Journal of Geophysical Research, v. 112, no. B10, pp. B10201, doi: 10.1029/2006JB004916.

Rosa, D.R.N., Inverno, C.M.C., Oliveira, V.M.J., and Rosa, C.J.P., 2004, Geochemistry of volcanic rocks, Albernoa area, Iberian pyrite belt, Portugal: International Geology Review, v. 46, no. 4, pp. 366-83.

Rosa, D.R.N., Inverno, C.M.C., Oliveira, V.M.J., and Rosa, C.J.P., 2006, Geochemistry and geothermometry of volcanic rocks from Serra Branca, Iberian pyrite belt, Portugal: Gondwana Res., v. 10, no. 3-4, pp. 328-39.

Schaaf, P., Stimac, J., Siebe, C., and Macías, J.L., 2005, Geochemical evidence for mantle origin and crustal processes in volcanic rocks from Popocatépetl and surrounding monogenetic volcanoes, central Mexico: Journal of Petrology, v. 46, no. 6, pp. 1243-82.

Schuth, S., Rohrbach, A., Münker, C., Ballhaus, C., Garbe-Schönberg, D., and Qopoto, C., 2004, Geochemical constraints on the petrogenesis of arc picrites and basalts, New Georgia group, Solomon islands: Contributions to Mineralogy and Petrology, v. 148, no. 3, pp. 288-304.

Schuth, S., Münker, C., Konig, S., Qopoto, C., Basi, S., Garbe-Schönberg, D., and Ballhaus, C., 2009, Petrogenesis of lavas along the Solomon island arc, SW Pacific: coupling of compositional variations and subduction zone geometry: Journal of Petrology, v. 50, no. 5, pp. 781-811.

Shane, P., Smith, V.C., and Nairn, I.A., 2005, High temperature rhyodacites of the 36 ka Hauparu pyroclastic eruption, Okataina volcanic centre, New Zealand: Change in a silicic magmatic system following caldera collapse: Journal of Volcanology and Geothermal Research, v. 147, no. $3-4$, pp. 357-76.

Sheth, H.C., and Melluso, L., 2008, The Mount Pavagadh volcanic suite, Deccan Traps: geochemical stratigraphy and magmatic evolution: Journal of Asian Earth Sciences, v. 32, no. 1, pp. 5-21.

Sheth, H.C., Mahoney, J.J., and Baxter, A.N., 2003, Geochemistry of lavas from Mauritius, Indian ocean: mantle sources and petrogenesis: International Geology Review, v. 45, no. 9, pp. 780-797.

Shinjo, R., Chekol, T., Meshesha, D., Itaya, T., and Tatsumi, Y., 2011, Geochemistry and geochronology of the mafic lavas from the southeastern Ethiopian rift (the East African Rift System): assessment of models on magma sources, plume-lithosphere interaction and plume evolution: Contributions to Mineralogy and Petrology, v. 162, no. 1, pp. 209-30.

Shukuno, H., Tamura, Y., Tani, K., Chang, Q., Suzuki, T., and Fiske, R.S. 2006, Origin of silicic magmas and the compositional gap at Sumisu submarine caldera, Izu-Bonin arc, Japan: Journal of Volcanology and Geothermal Research, v. 156 , no. 3-4, pp. 187-216.

Siebert, L., and Carrasco-Núñez, G., 2002, Late-Pleistocene to preColumbian behind-the-arc mafic volcanism in the eastern Mexican Volcanic Belt; implications for future hazards: Journal of Volcanology and Geothermal Research, v. 115 , no. $1-2$, pp. 179-205.

Späth, A., Le Roex, A.P., and Opiyo-Akech, N., 2001, Plume-lithosphere interaction and the origin of continental rift-related alkaline volcanismthe Chyulu Hills volcanic province, southern Kenya: Journal of Petrology, v. 42 , no. 4 , pp. $765-87$.

Srivastava, R.K., 2006, Geochemistry and petrogenesis of Neoarchaean high$\mathrm{Mg}$ low-Ti mafic igneous rocks in an intracratonic setting, central India craton: evidence for boninite magmatism: Geochemical Journal, v. 40, no. 1 , pp. 15-31.

Sruoga, P., Llambías, E.J., Fauqué, L., Schonwandt, D., and Repol, D.G., 2005, Volcanological and geochemical evolution of the Diamante caldera- 
Maipo volcano complex in the southern Andes of Argentina (34 $\left.10^{\prime} \mathrm{S}\right)$ : Journal of South American Earth Sciences, v. 19, no. 4, pp. 399-414.

Streckeisen, A.L., 1974, Classification and Nomenclature of Plutonic Rocks. Recommendations of the IUGS Subcommission on the Systematics of Igneous Rocks: Geologische Rundschau. Internationale Zeitschrift für Geologie Stuttgart, v.63, no. , pp. 773-785.

Streckeisen, A., 1976, To each plutonic rock its proper name: Earth Science Reviews, v. 12, no. 1, pp. 1-33.

Streckeisen, A.L., 1978, IUGS Subcommission on the Systematics of Igneous Rocks. Classification and Nomenclature of Volcanic Rocks, Lamprophyres, Carbonatites and Melilite Rocks. Recommendations and Suggestions: Neues Jahrbuch für Mineralogie, Abhandlungen, v. 141, no. , pp. 1-14.

Tamura, Y., Gill, J.B., Tollstrup, D., Kawabata, H., Shukuno, H., Chang, Q., Miyazaki, T., Takahashi, T., Hirahara, Y., Kodaira, S., Ishizuka, O., Suzuki, T., Kido, Y., Fiske, R.S., and Tatsumi, Y., 2009, Silicic magmas in the Izu-Bonin oceanic arc and implications for crustal evolution: Journal of Petrology, v. 50, no. 4, pp. 685-723.

Tappe, S., Jenner, G.A., Foley, S.F., Heaman, L., Besserer, D., Kjarsgaard, B.A., and Ryan, B., 2004, Torngat ultramafic lamprophyres and their relation to the North Atlantic alkaline province: Lithos, v. 76, no. 1-4, pp. 491- 518.

Tatar, O., Yurtmen, S., Temiz, H., Gursoy, H., Kocbulut, F., Mesci, B.L., and Guezou, J.C., 2007, Intracontinental Quaternary volcanism in the Niksar pull-apart basin, North Anatolian Fault Zone, Turkey: Turkish Journal of Earth Sciences, v. 16, no. 4, pp. 417-40.

Taylor, R.N., Nesbitt, R.W., Vidal, P., Harmon, R.S., Auvray, B., and Croudace, I.W., 1994, Mineralogy, chemistry, and genesis of the boninite series volcanics, Chichijima, Bonin Islands, Japan: Journal of Petrology, v. 35, no. 3, pp. 577-617.

Tian, L., Castillo, P.R., Lonsdale, P.F., Hahm, D., and Hilton, D.R., 2011, Petrology and $\mathrm{Sr} \bullet \mathrm{Nd} \bullet \mathrm{Pb} \bullet \mathrm{He}$ isotope geochemistry of postspreading lavas on fossil spreading axes off Baja California Sur, Mexico: Geochemistry Geophysics Geosystems, v. 12, no. 2, pp. doi:10.1029/ 2010GC003319.

Torabi, G., 2009, Subduction-related Eocene shoshonites from the Cenozoic Urumieh-Dokhtar magmatic arc (Qaleh-Khargooshi area, western Yazd province, Iran): Turkish Journal of Earth Sciences, v. 18, no. 4, pp. 583613.

Turner, S., Caulfield, J., Rushmer, T., Turner, M., Cronin, S., Smith, I., and Handley, H., 2012, Magma evolution in the primitive, Intra-oceanic Tonga Arc: rapid petrogenesis of dacites at Fonualei volcano: Journal of Petrology, v. 53, no. 6, pp. 1231-53.

Upton, B.G.J., Semet, M.P., and Joron, J.-L., 2000, Cumulate clasts in the Bellecombe ash member, Piton de la Fournaise, Réunion island, and their bearing on cumulative processes in the petrogenesis of the Réunion lavas: Journal of Volcanology and Geothermal Research, v. 104, no. 1-4, pp. 297-318.

Verma, S.K., Pandarinath, K., and Verma, S.P., 2012, Statistical evaluation of tectonomagmatic discrimination diagrams for granitic rocks and proposal of new discriminant-function-based multi-dimensional diagrams for acid rocks: International Geology Review, v. 54, no. 3, pp. 325-347.

Verma, S.P., 2000, Geochemistry of the subducting Cocos plate and the origin of subduction-unrelated mafic volcanism at the volcanic front of the central Mexican Volcanic Belt, in Delgado-Granados, H., Aguirre-Díaz, G., and Stock, J.M., eds, Cenozoic tectonics and volcanism of Mexico: Boulder, Colorado, Geological Society of America, pp. 195-222.

Verma, S.P., 2010, Statistical evaluation of bivariate, ternary and discriminant function tectonomagmatic discrimination diagrams: Turkish Journal of Earth Sciences, v. 19, no. 2, pp. 185-238.

Verma, S.P., 2012, Application of multi-dimensional discrimination diagrams

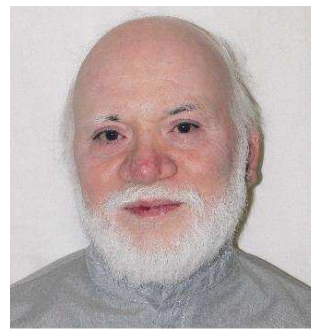

Surendra P. Verma is a senior scientist at the Universidad Nacional Autónoma de México. He received $\mathrm{PhD}$ degree from Indian Institute of Science, Bangalore, India in 1971. He has published more than 200 papers His scientific interest includes igneous and sedimentary rock geochemistry, computer programming, Monte Carlo simulations and statistics. and probability calculations to acid rocks from Portugal and Spain: Comunicações Geológicas, v. 99, no. 2, pp. 79-93.

Verma, S.P. and Agrawal, S., 2011, New tectonic discrimination diagrams for basic and ultrabasic volcanic rocks through log-transformed ratios of high field strength elements and implications for petrogenetic processes: Revista Mexicana de Ciencias Geológicas, v. 28, no. 1, pp. 24-44.

Verma, S.P., Torres-Alvarado, I.S., and Sotelo-Rodríguez, Z.T., 2002, SINCLAS: standard igneous norm and volcanic rock classification system: Computers \& Geosciences, v. 28, no. 5, pp. 711-715.

Verma, S.P., Torres-Alvarado, I.S., and Velasco-Tapia, F., 2003, A revised CIPW norm: Schweizerische Mineralogische und Petrographische Mitteilungen, v. 83, no. 2, pp. 197-216.

Verma, S.P., Guevara, M., and Agrawal, S., 2006, Discriminating four tectonic settings: five new geochemical diagrams for basic and ultrabasic volcanic rocks based on log-ratio transformation of major-element data: Journal of Earth System Science, v. 115, no. 5, pp. 485-528.

Verma, S.P., Rodríguez-Ríos, R., and González-Ramírez, R., 2010, Statistical evaluation of classification diagrams for altered ignous rocks: Turkish Journal of Earth Sciences, v. 19, no. 2, pp. 239-265.

Vigouroux, N., Wallace, P.J., and Kent, A.J.R., 2008, Volatiles in high-K magmas from the western Trans-Mexican Volcanic Belt: evidence for fluid fluxing and extreme enrichment of the mantle wedge by subduction processes: Journal of Petrology, v. 49, no. 9, pp. 1589-618.

Wang, X.-C., Li, Z.-X.-., Li, X.-H., Li, J., Liu, Y., Long, W.-G., Zhou, J.-B., and Wang, F., 2012, Temperature, pressure, and composition of the mantle source region of Late Cenozoic basalts in Hainan Island, SE Asia: a consequence of a young thermal mantle plume close to subduction zones?: Journal of Petrology, v. 53, no. 1, pp. 177-233.

Watts, K.E., Bindeman, I.N., and Schmitt, A.K., 2011, Large-volume rhyolite genesis in caldera complexes of the Snake River Plain: insights from the Kilgore tuff of the Heise volcanic field, Idaho, with comparison to Yellowstone and Bruneau-Jarbidge rhyolites: Journal of Petrology, v. 52, no. 5, pp. 857-90.

Woodard, J., and Hölttä, P., 2005, The Naantali alvikite vein-dykes: a new carbonatite in southwestern Finland: Geological Survey of Finland Special Paper, v. 38, no., pp. 5-10.

Zaitsev, A.N., Marks, M.A.W., Wenzel, T., Spratt, J., Sharygin, V.V., Strekopytov, S., and Markl, G., 2010, Mineralogy, geochemistry and petrology of the phonolitic to nephelinitic Sadiman volcano, Crater Highlands, Tanzania: Lithos, doi:10.1016/j.lithos.2012.03.001, in press.

Zellmer, G.F., and Turner, S.P., 2007, Arc dacite genesis pathways: Evidence from mafic enclaves and their hosts in Aegean lavas: Lithos, v. 95, no. 34, pp. 346-62.

Zellmer, G., Turner, S., and Hawkesworth, C., 2000, Time scales of destructive plate margin magmatism: new insights from Santorini, Aegean volcanic arc: Earth and Planetary Science Letters, v. 174, no. 3-4, pp. 265-81.

Zhang, Q., Wang, Y., Zhou, G.Q., Qian, Q., and Robinson, P.T., 2003, Ophiolites in China: their distribution, ages and tectonic settings, in Dilek, Y., and Robinson, P.T., eds, Ophiolites in Earth History: Bath, U.K., Geological Society of London, pp. 541-66.

Zongfeng, Y., Zhaohua, L., Huafeng, Z., Yongmei, Z., Fan, H., Chenguang, S., and Jingen, D., 2009, Petrogenesis and Geological Implications of the Tianheyong Cenozoic Basalts, Inner Mongolia China: Earth Science Frontiers, v. 16, no. 2, pp. 90-106.

Zou, H., Reid, M.R., Liu, Y., Yao, Y., Xu, X., and Fan, Q., 2003, Constraints on the origin of historic potassic basalts from northeast China by U-Th disequilibrium data: Chemical Geology, v. 200, no. 1-2, pp. 189-201.

Zou, H., Fan, Q., and Yao, Y., 2008, U-Th systematics of dispersed young volcanoes in NE China: Asthenosphere upwelling caused by piling up and upward thickening of stagnant Pacific slab: Chemical Geology, v. 255 , no. $1-2$, pp. $134-42$.

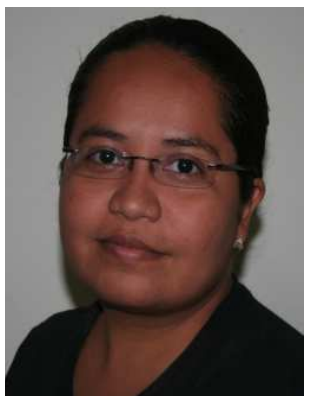

M. Abdelaly Rivera-Gómez completed her Master's degree in Energy Engineering at the Universidad Nacional Autónoma de México in 2010. She is currently applying for scholarship to pursue her doctoral studies in Energy Engineering. She holds a Bachelor degree in Computer Programming (2007), which has been an asset in the development of IgRoCS software outlined in this review. 